\title{
Aplikasi campuran serbuk kayu pinus dan fipronil sebagai umpan rayap tanah Macrotermes gilvus (Hagen) (Isoptera: Termitidae) di Bandung
}

\author{
Application of fipronil-treated pinewood sawdust as bait for \\ subterranean termite, Macrotermes gilvus (Isoptera: Termitidae) \\ in Bandung
}

\author{
Amran, Intan Ahmad*, Ramadhani Eka Putra, Eko Kuswanto \\ Sekolah Ilmu dan Teknologi Hayati, Institut Teknologi Bandung \\ Jalan Ganesha No. 10 Bandung 40132
}

(diterima Juli 2014, disetujui Desember 2014)

\begin{abstract}
ABSTRAK
Penelitian ini bertujuan untuk menguji penggunaan umpan serbuk kayu pinus yang dicampur dengan insektisida berdaya kerja lambat fipronil, dalam mengendalikan rayap tanah Macrotermes gilvus (Hagen) (Isoptera: Termitidae) di Bandung. Pada penelitian ini juga dilakukan pendugaan ukuran koloni rayap dengan menggunakan metode capture-mark-release-recapture, serta berat kayu yang dimakan untuk setiap stasiun pengamatan. Hasil perkiraan menunjukkan bahwa 77.951 individu rayap pekerja berada di daerah teritori seluas $234 \mathrm{~m}^{2}$, dengan banyaknya konsumsi kayu berkisar antara 0,02-6,16 g/stasiun/hari selama empat bulan pengamatan. Pengamatan pada 18 stasiun yang telah diberi umpan yang terbuat dari campuran 40 ppm fipronil dan serbuk kayu pinus menunjukkan bahwa setelah 40 hari aplikasi umpan telah terjadi penurunan aktivitas mencari makan dari rayap pekerja $M$. gilvus. Oleh karena itu, dapat disimpulkan bahwa campuran serbuk kayu pinus dan fipronil efektif dalam menekan populasi rayap pekerja $M$. gilvus, yang berperan sebagai pencari makan dalam waktu 40 hari.
\end{abstract}

Kata kunci: pengendalian, populasi, rayap pekerja, umpan bercampur insektisida

\begin{abstract}
In this study, termite bait comprising of pinewood of sawdust and a slow action insecticide, fipronil, was made and applied to control subterranean termite Macrotermes gilvus (Hagen) (Isoptera: Termitidae) in Bandung. Colony size was measured using capture-mark-release-recapture prior to the bait application, along with the measurement of wood consumption at each station. Colony foraging populations at all stations were estimated to be 77,951 termites, with mean wood consumption rates ranging from 0.02 to $6.16 \mathrm{~g} /$ station/day. Observation at 18 stations installed with bait consisted of 40 ppm fipronil mixed with pinewood sawdust showed that number of foraging activity termites was effectively reduced in 40 days. It is concluded that fipronil-treated pinewood sawdust bait is effective in controlling the population of foraging M. gilvus workers in 40 days.
\end{abstract}

Key words: control, bait imbeded with insecticide, population, worker termites

\footnotetext{
*Penulis korespondensi: Intan Ahmad. Sekolah Ilmu dan Teknologi Hayati, Institut Teknologi Bandung Jalan Ganesha No. 10, Bandung 40132

Tel: 022-2511575, Faks: 022-2515033, Email: intan@itb.ac.id
} 


\section{PENDAHULUAN}

Rayap sebagai hama telah menimbulkan kerugian ekonomis yang sangat besar. Di lingkungan permukiman, rayap seringkali merusak kayu sebagai bagian dari konstruksi bangunan dan material berselulosa lainnya di dalam bangunan gedung (Tarumingkeng 2001). Walau tidak ada data yang akurat mengenai estimasi kerugian ekonomis yang ditimbulkan akibat serangan rayap di Indonesia, tetapi khusus untuk kota Bandung penelitian terbaru yang dilakukan oleh Sobri (2013) memperkirakan nilai kerugian akibat serangan rayap mencapai 1,37 trilyun rupiah.

Di Indonesia, jenis rayap yang paling menyebabkan kerugian secara ekonomi adalah genus Coptotermes (Nandika et al. 2003; Tarumingkeng et al. 2005). Di negara lain, selain Coptotermes, Reticulitermes adalah jenis rayap yang banyak menimbulkan kerugian secara ekonomi, seperti di Amerika Serikat (Su \& Scheffrahn 1998), Thailand (Sornnuwat et al. 2003), Malaysia (Sajap et al. 2000), dan Jepang (Miura 2004).

Untuk Indonesia, upaya pengendalian terhadap kedua genus rayap tersebut selama ini lebih banyak ditujukan kepada Coptotermes karena jenis rayap ini banyak dilaporkan menyerang bangunan pada lingkungan pemukiman di kota-kota besar antara lain di Jakarta, Padang, Surabaya, dan Medan (Safarudin 1994; Jusmalinda 1994; Munif 1995; Siregar \& Batubara 2007).

Pengendalian rayap yang paling banyak dilakukan di Indonesia adalah dengan menggunakan termitisida tanah. Walaupun demikian, cara ini menimbulkan kendala seperti yang banyak dilaporkan di Amerika Serikat dan negara-negara lain bahwa selain biayanya tinggi dan hasilnya tidak efektif karena memiliki sedikit efek langsung pada rayap, juga membunuh organisme non target, dan dapat mencemari lingkungan ( $\mathrm{Su} \&$ Scheffrahn 1998). Oleh karena itu, agar pengendalian rayap dapat lebih tepat sasaran maka teknologi pengendalian rayap dengan menggunakan umpan telah dikembangkan. Teknologi umpan merupakan cara yang paling efektif, aman, dan ramah lingkungan karena racun dapat dimasukkan ke dalam umpan untuk menghilangkan koloni rayap (Huang et al. 2006).

Walaupun insektisida berbahan aktif fipronil telah banyak digunakan sebagai termitisida tanah di Indonesia, tetapi informasi yang berkenaan dengan aplikasi umpan berbasis fipronil untuk mengendalikan rayap, terutama Macrotermes yang potensi merusaknya pada bangunan tidak kalah besar dibandingkan dengan Coptotermes, belum pernah dilaporkan. Oleh karena itu, penelitian ini dilakukan untuk mengetahui efek yang diberikan oleh campuran umpan dan fipronil terhadap aktivitas, terutama aktivitas mencari makan, dari koloni rayap Macrotermes gilvus (Hagen) (Isoptera: Termitidae) yang menyerang bangunan di Bandung.

\section{BAHAN DAN METODE}

\section{Tempat dan waktu penelitian}

Penelitian dilakukan di Pondok Karya Ganesha, Desa Melati Wangi, Kecamatan Cilengkrang selama 10 bulan, yaitu dari bulan Juli 2012-April 2013. Penentuan lokasi penelitian didasarkan hasil survei yang telah dilakukan pada 30 kecamatan di kota Bandung selama 6 bulan yang menunjukkan bahwa lokasi ini termasuk areal yang terinfestasi oleh rayap M. gilvus (Kuswanto, belum dipublikasikan).

\section{Estimasi ukuran populasi rayap}

Pembuatan kayu survei dan kayu monitor. Bolok kayu pinus (Pinus merkusii) berukuran $2,5 \mathrm{~cm}$ x $4,0 \mathrm{~cm}$ x $30 \mathrm{~cm}$ yang sudah dikeringkan dalam oven pada suhu $70{ }^{\circ} \mathrm{C}$ selama 48 jam digunakan sebagai bahan untuk kayu survei dan kayu monitor. Kayu survei adalah kayu yang digunakan untuk mengamati kehadiran rayap, sedangkan kayu monitor adalah yang dipasang pada stasiun pengamatan untuk menghitung jumlah individu, persentase kehilangan umpan, dan rata-rata konsumsi rayap. Kayu survei dan kayu monitor tidak mengandung insektisida.

Peletakan kayu survei. Survei dilakukan pada 4 (empat) rumah lokasi penelitian yang diduga terinfestasi oleh rayap. Kayu survei diletakkan di sekeliling rumah, dekat sistem perakaran tanaman atau daerah yang diperkirakan tidak terganggu oleh aktivitas manusia. Total jumlah kayu survei yang dipasang pada daerah pengamatan adalah 58 buah (17 buah kayu per rumah). Tujuan dari kegiatan ini adalah untuk menentukan lokasi dengan tingkat 
infestasi rayap tertinggi sebagai dasar untuk pengujian umpan kayu pinus yang telah dicampur dengan fipronil. Setiap kayu survei dibenamkan dalam tanah secara vertikal ke dalam tanah sedalam $5 \mathrm{~cm}$ dan bagian yang muncul di atas tanah setinggi $25 \mathrm{~cm}$, jarak antarkayu survei 1-1,5 m, dan jarak dari rumah adalah $0,5-2,0 \mathrm{~m}$. Pengamatan kayu survei dilakukan setiap bulan.

Pembuatan dan pemasangan stasiun pengamatan (kayu monitor). Stasiun pengamatan (monitor) dibuat dari pipa PVC (diameter $17 \mathrm{~cm}$; tinggi $15 \mathrm{~cm}$; tebal $0,8 \mathrm{~cm}$ ) dilakukan dengan mengacu kepada metode yang dikembangkan oleh Huang et al. (2006). Secara singkat pipa PVC dipotong sepanjang $30 \mathrm{~cm}$ kemudian dilubangi agar berfungsi sebagai jalan masuk rayap ke dalam stasiun (Gambar 1).

Titik penempatan stasiun pengamatan berdasarkan pada lokasi dimana kayu survei dikonsumsi oleh rayap. Tanah di sekeliling kayu umpan yang terserang rayap digali dan dibuang sehingga membentuk liang berdiameter $17 \mathrm{~cm}$ dengan kedalaman $13 \mathrm{~cm}$ sebagai lokasi penempatan stasiun pengamatan. Selanjutnya kayu umpan berukuran $2,5 \mathrm{~cm}$ x $2,5 \mathrm{~cm}$ x $30 \mathrm{~cm}$, yang telah dikeringkan pada suhu $105^{\circ} \mathrm{C}$ selama 24 jam dan ditimbang $\left(\mathrm{BKK}_{1}\right)$, dimasukkan ke dalam rongga di bagian tengah stasiun pengamatan. Lubang pada bagian atas ditutup dengan penutup yang terbuat dari plastik lalu stasiun ditutup kembali dengan tanah.

Setelah 4 bulan, kayu monitor dikoleksi, dicuci, dikeringkan pada oven dengan suhu $105^{\circ} \mathrm{C}$ selama $24 \mathrm{jam}$, lalu ditimbang $\left(\mathrm{BKK}_{2}\right)$. Selisih antara $\mathrm{BKK}_{1}$ dan $\mathrm{BKK}_{2}$ diasumsikan sebagai aktivitas makan dari koloni rayap yang ada.
Estimasi jumlah individu rayap. Untuk mengetahui ukuran populasi rayap kembara, serta teritorinya dilakukan pengamatan menggunakan metode capture-mark-recapture release (CMRR) sesuai rumus dari Lincoln Peterson (Seber 1973).

$$
\mathrm{N}=\frac{\mathrm{M} \cdot \mathrm{N}}{\mathrm{R}} \text {, dengan }
$$

$\mathrm{N}$ : perkiraan ukuran total populasi; M: jumlah hewan ditangkap dan ditandai pada kunjungan pertama; C: total jumlah hewan yang diambil pada kunjungan kedua; R: jumlah hewan ditangkap pada kunjungan pertama yang kemudian ditangkap kembali pada kunjungan kedua.

Protokol Mark-Recapture yang dikembangkan oleh Evans et al. (1998) digunakan dalam penelitian ini, dengan menggunakan serbuk pewarna makanan "ontan" berwarna merah yang dilarutkan dalam air dengan perbandingan 5,60 g : $150 \mathrm{ml}$ air untuk menandai rayap yang tertangkap.

\section{Uji efektivitas umpan}

Bahan utama dalam pembuatan umpan adalah serbuk kayu pinus yang dikeringkan dalam oven pada suhu $70{ }^{\circ} \mathrm{C}$ selama 48 jam. Serbuk kayu di campur dengan fipronil sehingga diperoleh konsentrasi 40 ppm (Huang et al. 2006). Pada penelitian ini, lokasi aplikasi adalah pada lokasi dimana aktivitas rayap telah ditemui dan terukur berdasarkan pengamatan menggunakan stasiun pengamatan. Proses aplikasi menggunakan stasiun pengamatan. Umpan sebanyak $78 \mathrm{~g}$ dimasukkan ke dalam stasiun pengamatan pada rongga dimana kayu monitor sebelumnya ditempatkan. Bersamaan dengan penempatan stasiun pengamatan berisi umpan, stasiun survei juga ditempatkan pada titik

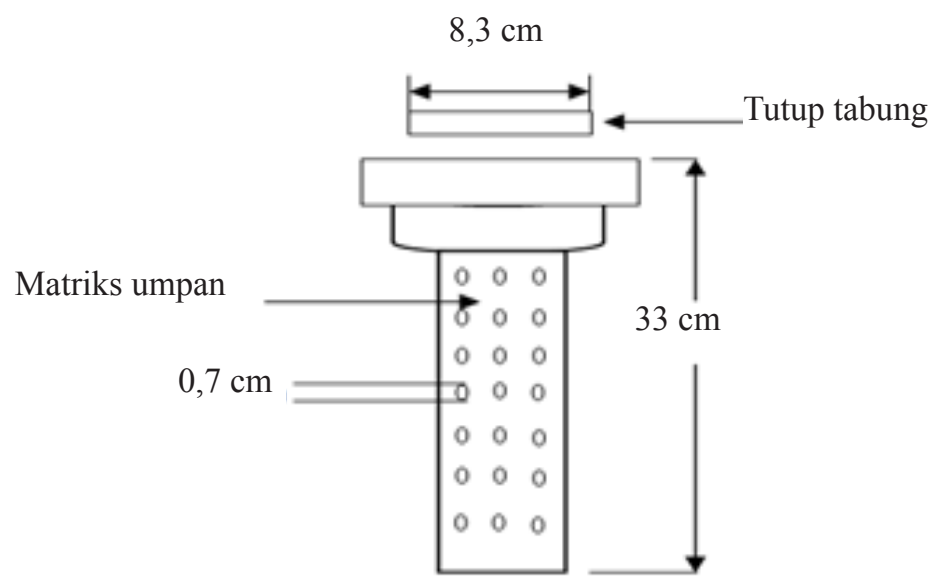

Gambar 1. Stasiun pengamatan. 
yang berdekatan dengan stasiun pengamatan tersebut. Setiap hari dilakukan pengamatan aktivitas rayap pada stasiun pengamatan pada pukul 18:00 20:00. Pengamatan dilakukan hingga tidak ditemukan lagi aktivitas rayap pada umpan dan stasiun survei.

\section{HASIL}

\section{Kehadiran rayap pada kayu survei}

Pada penelitian ini, kayu survei pada 22 titik pengamatan (38\% dari total titik pengamatan) berhasil mendeteksi keberadaan rayap selama 4 bulan pengamatan. Hasil penelitian ini juga menunjukkan dibutuhkan waktu sekurang-kurangnya 1 bulan untuk dapat mendeteksi keberadaan rayap menggunakan kayu survei (Gambar 2).

\section{Estimasi jumlah individu rayap kembara}

Pada penentuan nilai estimasi jumlah individu rayap, hanya 6 stasiun pengamatan (dari 22 stasiun pengamatan) yang mendeteksi aktivitas rayap. Berdasarkan hasil perhitungan meng- gunakan metoda CMRR pada ke-6 stasiun ini maka diperkirakan jumlah populasi rayap pada setiap stasiun pengamatan bervariasi antara 500 hingga 23.000 individu rayap. Secara total (dengan menghitung dugaan jumlah rayap pada setiap stasiun pengamatan), diperkirakan jumlah rayap adalah 77.951 individu (Gambar 3).

\section{Konsumsi kayu monitor}

Terdapat 6 stasiun pengamatan yang mendeteksi aktivitas mencari makan rayap (pada penelitian ini adalah stasiun $3,6,7,10,11$, dan 12). Konsumsi kayu monitor pada setiap stasiun pengamatan $0,02-6,16 \mathrm{~g} / \mathrm{stasiun} / \mathrm{hari}$ berdasarkan data dari empat bulan pengamatan dengan asumsi total populasi rayap sebesar 77.951 individu (Gambar 4).

\section{Efektivitas umpan fipronil}

Pengamatan pada stasiun survei menunjukkan bahwa empat puluh hari setelah pemberian umpan di lokasi penelitian tidak ada lagi ditemukan aktivitas mencari makan populasi kembara $M$. gilvus.

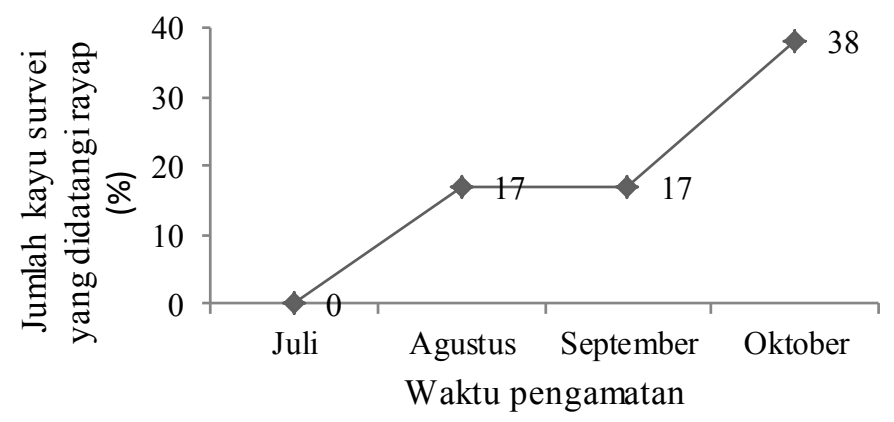

Gambar 2. Grafik persentase kehadiran rayap.

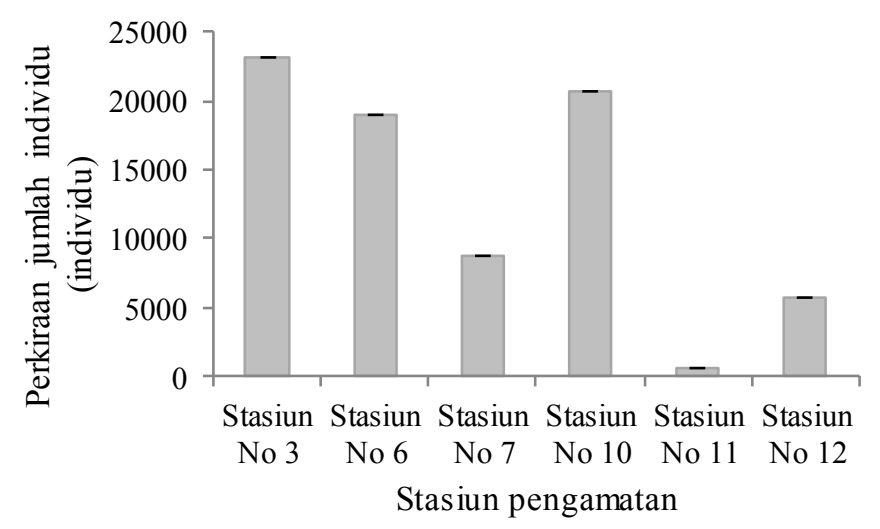

Gambar 3. Jumlah individu rayap Macrotermes gilvus di Pondok Ganesha Desa Melatiwangi. 


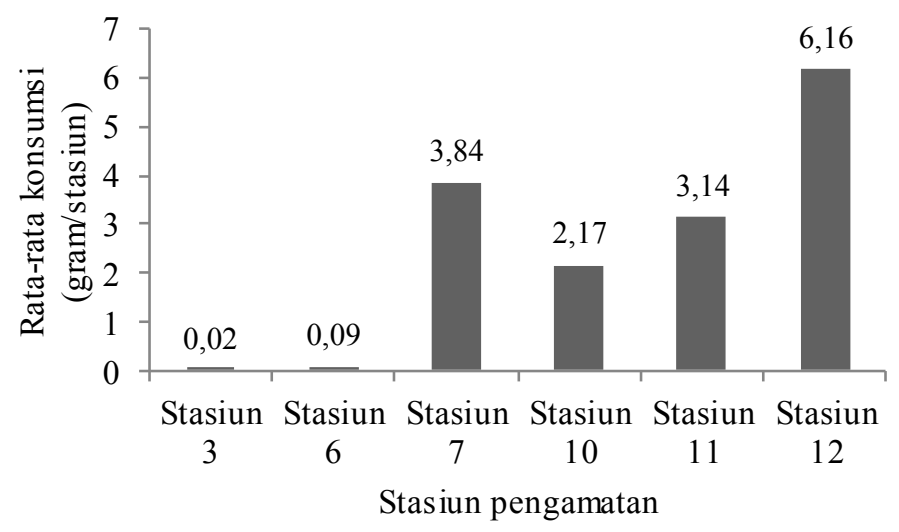

Gambar 4. Jumlah rata-rata konsumsi kayu monitor per individu dalam koloni rayap Macrotermes gilvus di Pondok Ganesha Desa Melatiwangi.

\section{PEMBAHASAN}

Kedatangan rayap pada kayu survei bisa menjelaskan bahwa kayu pinus merupakan kayu yang disukai oleh rayap sebagai sumber makanannya. Hasil penelitian ini juga memperkuat informasi yang pernah dilaporkan oleh Arinana et al. (2012) bahwa umpan kayu $P$. merkusii amat disukai oleh M. gilvus, diikuti oleh Coptotermes curvignathus (Desneux), tetapi kurang disukai oleh Capritermes mohri (Kemner).

Perhitungan jumlah populasi rayap pada penelitian ini mirip dengan yang dilaporkan oleh Sajap et al. (2000) bahwa empat koloni rayap $M$. gilvus yang terdapat di Kampus Universiti Putra Malaysia, Serdang, Malaysia mempunyai jumlah individu berkisar antara 166.288-709.052 individu. Penelitian lainnya oleh Su (1994) di Amerika Serikat memperkirakan ukuran populasi dari koloni Reticulitermes flavipes (Kollar) dan Coptotermes formosanus (Shiraki) sebesar $104.000 \pm 5.000$ individu. Walaupun demikian, perlu dicatat di sini bahwa metode ini hanya dapat memperkirakan jumlah rayap kembara saja, dan bukan ukuran koloni secara keseluruhan. Selain itu, metode mark-recapture masih ada kelemahannya karena dihitung berdasarkan rayap bertanda yang ditangkap kembali yang mungkin dapat mengakibatkan tidak akuratnya perhitungan jumlah rayap karena adanya kemungkinan bahwa warna dapat ditransfer ke rayap lain melalui proses kanibalisme (Evans et al. 1999).

Tingkat konsumsi kayu/stasiun yang diperoleh pada penelitian Sajap et al. (2000) yang menunjukkan rata-rata konsumsi kayu sebanyak
10,20-16,94 g/stasiun/hari berdasarkan pengamatan selama 15 bulan untuk jumlah populasi rayap pekerja berkisar antara 166.288-709.052. Adanya perbedaan konsumsi kayu/stasiun/hari dari kedua penelitian di atas, nampaknya amat ditentukan oleh jumlah rayap kembara (ukuran koloni) serta lamanya penelitian dilakukan.

Hasil penelitian menunjukkan bahwa hanya dalam waktu yang relatif singkat, yaitu empat puluh hari setelah pemberian umpan ternyata di lokasi penelitian tidak ada lagi ditemukan aktivitas mencari makan rayap M. gilvus. Hasil ini mirip dengan penelitian pengendalian Odontotermes formosanus Shiraki (Termitidae) menggunakan fipronil yang dilakukan oleh Huang et al. (2006) di Wuhan, China, walaupun mereka baru dapat mengendalikan rayap setelah empat bulan umpan diletakkan. Penelitian lainnya yang dilakukan dengan menggunakan umpan rayap berbahan aktif noviflumuron, suatu inhibitor sintesis kitin, berhasil mengendalikan 122 koloni berbagai rayap tanah (Termitidae) dalam waktu kurang dari satu tahun (Eger et al. 2012). Hasil penelitian ini menunjukkan bahwa $M$ gilvus sebagai anggota famili Termitidae dapat juga dikendalikan dengan menggunakan umpan, walaupun cara kerja yang pasti bagaimana umpan yang mengandung fipronil ditransfer ke dalam koloni belum dapat dijelaskan, tetapi diperkirakan hal ini dilakukan dengan cara trofalaksis antara rayap kembara dengan anggota koloni lainnya. Selain itu, hasil penelitian ini juga memberikan konfirmasi bahwa ternyata teknologi umpan dapat juga digunakan untuk mengendalikan rayap dari famili Termitidae, seperti yang telah dilakukan oleh Huang et al. (2006) dan juga 
Dhang (2011). Temuan ini menarik karena para peneliti lainnya pada umumnya, berdasarkan pengamatan sebelumnya di Malaysia, Thailand, Singapura, Indonesia, dan Australia (Lee et al. 2007) menyatakan bahwa umpan hanya efektif terhadap rayap anggota famili Rhinotermitidae (genus Coptotermes dan Schedorhinotermes) dan bukan untuk Termitidae. Terjadinya perbedaan hasil penelitian di atas antara rayap dari famili Rhinotermitidae dan Termitidae, kemungkinan dapat juga disebabkan oleh berbedanya kayu umpan yang digunakan serta lokasi keberadaan rayap. Tetapi yang menarik, ternyata kayu pinus yang umumnya dikenal sebagai salah satu makanan rayap dari genus Coptotermes (Rhinotermitidae) (Ngee et al. 2004), ternyata juga merupakan umpan yang baik bagi M. gilvus (Termitidae) yang ditemukan dalam penelitian ini.

\section{KESIMPULAN}

Perkiraan jumlah rayap kembara dari koloni M. gilvus dapat dihitung dengan metode capturemark-recapture release, serta umpan berbasis fipronil dengan konsentrasi 40 ppm efektif dalam menekan populasi rayap kembara M. gilvus dalam waktu 40 hari.

\section{UCAPAN TERIMA KASIH}

Terima kasih ditujukan kepada pihak Dinas Pendidikan dan Kebudayaan Daerah Provinsi Sulawesi Tengah yang telah memberikan beasiswa kepada penulis pertama, serta kepada Bapak Tatang Friatna, yang telah menyediakan lokasi untuk penelitian ini.

\section{DAFTAR PUSTAKA}

Arinana, Haneda NF, Kahar TP. 2012. Diversity and distribution of termite species on oil palm plantation at the PTP Nusantara VIII Bogor, West Java-Indonesia. In: Proceedings of the 9th Pacific-Rim Termite Research Group Conference (Hanoi, 27-28 February 2012). pp: 148-155. Hanoi: Pacific-Rim Termite Research Group.
Dhang P. 2011. A preliminary study on elimination of colonies of the mound building termite Macrotermes gilvus (Hagen) using a chlorfluazuron termite bait in the Philippines. Insects 2:486-490. doi: http://dx.doi.org/10.3390/insects 2040486.

Eger JE, Lees MD, Neese PA, Atkinson TH, Thoms EM, Messenger MT, Demark JJ, Lee LC, Vargo EL, Tolley MPE. 2012. Elimination of subterranean termite (Isoptera: Rhinotermitidae) colonies using a refined cellulose bait matrix containing noviflumuron when monitored and replenished quarterly. Journal of Economic Entomology 105:533-9. doi: http://dx.doi.org/10. 1603/EC11027.

Evans T, Lanz M, Gleeson PV. 1998. Testing assumption of mark-recapture protocols for estimating size using Australian mound-building, subterranean termites. Ecological Entomology 23:139-159. doi: http://dx.doi.org/10.1046/j.1365 -2311.1998.00114.x.

Evans TA, Lenz M, Gleeson PV. 1999. Estimating population size and forager movement in a tropical subterranean termite (Isoptera: Rhinotermitidae). Environmental Entomology 28:823830. doi: http://dx.doi.org/10.1093/ee/28.5.823.

Huang QY, Lei CL, Xue D. 2006. Field evaluation of a fipronil bait against subterranean termite Odontotermes formosanus (Isoptera: Termitidae). Journal of Economic Entomology 99:455-461. doi: http://dx.doi.org/10.1093/jee/99.2.455.

Jusmalinda. 1994. Perkiraan Kerugian Ekonomis Akibat Serangan Rayap pada Bangunan Rumah Rakyat di Tiga Kecamatan Propinsi Sumatera Barat. Skripsi. Bogor: Institut Pertanian Bogor.

Lee CY, Vongkaluang C, Lenz D. 2007. Challenges to subterranean termite management of multigenera faunas in Southeast Asia and Australia. Sociobiology 50:213-221.

Miura T. 2004. Proximate mechanism and evolution of caste polyphenism in social insects: from sociality to genes. Ecological Research 19:141148. doi: http://dx.doi.org/10.1111/j.1440-1703. 2003.00618.x.

Munif A. 1995. Keanekaragaman Rayap Perusak Bangunan Dan Kasus Serangannya Pada Perumahan di Kotamadya Surabaya. Skripsi. Bogor: Institut Pertanian Bogor.

Nandika D, Rismayadi Y, Diba F. 2003. Rayap, Biologi dan Pengendaliannya. Surakarta: Muhammadiyah University Press.

Ngee PS, Tashiro A, Yoshimura T, Jaal Z, Lee CY. 2004. Wood preference of selected Malaysian 
subterranean termites (Isoptera: Rhinotermitidae, termitidae). Sociobiology 43:535-550.

Safarudin. 1994. Kerugian Ekonomi Akibat Serangan Rayap pada bangunan Perumahan di dua Wilayah DKI Jakarta (Kotamadya Jakarta Barat dan Jakarta Timur). Skripsi. Bogor: Institut Pertanian Bogor.

Sajap AS, Amit S, Welker J. 2000. Evaluation of hexaflumuron for controlling the subterranean termite Coptotermes curvignathus (Isoptera: Rhinotermitidae) in Malaysia. Journal of Economic Entomology 93:429-433. doi: http:// dx.doi.org/10.1603/0022-0493-93.2.429.

Seber GAF. 1973. The estimation of animal abundance and related parameters. Biometrics 42:267-292. doi: http://dx.doi.org/10.2307/2531049.

Siregar AZ, Batubara R. 2007. Kerugian ekonomis akibat serangan rayap pada bangunan rumah masyarakat di dua Kecamatan (Medan Denai dan Medan Labuhan). Jurnal Biologi Sumatera 2: 23-27.

Sobri. 2013. Survei Keragaman Jenis Rayap dan Estimasi Kerugian Ekonomi Akibat Serangannya pada Lingkungan Permukiman di Kota Bandung. Tesis. Bandung: Institut Teknologi Bandung.

Sornnuwat Y, Charoenkrung K, Chutibhapakorn S, Vongkaluang C. 2003. Termite survey in secondary dry dipterocarp forest at Srinakarin
Dam National Park, Kanchanaburi Province, Western Thailand. In: Proceedings of The 2nd International Conference on Medicinal Mushroom and the International Conference Biodiversity and Bioactive Compounds (Pattaya, 17-19 July 2003). pp. 517-522. Pattaya: National Science and Technology Development Agency. National Center for Genetic Engineering and Biotechnology.

Su NY. 1994. Field evaluation of a hexaflumuron bait for population suppression of subterranean termites (Isoptera: Rhinotermitidae). Journal of Economic Entomology 87:389-397. doi: http:// dx.doi.org/10.1093/jee/87.2.389.

Su NY, Scheffrahn RH. 1998. Areview of subterranean termite control practices and prospects for integrated pest management programmes. Integrated Pest Management Reviews 3:1-13. doi: http://dx.doi.org/10.1023/A:1009684821954.

Tarumingkeng RC. 2001. Biologi dan Perilaku Rayap (Biology and Ethology of Termites). Bogor: Institut Pertanian Bogor.

Tarumingkeng RC, Surjokusumo S, Solihin DD. 2005. Pengendalian Hama Terpadu Rayap Tanah Coptotermes Pada Kawasan Pemukiman Berdasarkan Karakter Genetik di Pulau Jawa. Research Report. Bogor: Lembaga Penelitian dan Pengabdian Masyarakat-lnstitut Pertanian Bogor. 